\title{
How Electronic General Meetings Affected Exercise of Shareholder Rights in Turkey: An Analysis of the Turkish Model in Light of International Market Standards and Regulations
}

\author{
Yakup Ergincan* \\ Merkezi Kayıt Kurulu A.Ş.
}

\author{
Bora Karaağaçlı ** \\ Merkezi Kayıt Kurulu A.Ş
}

\begin{abstract}
This paper discusses the impacts of the introduction of electronic general meetings on shareholder participation in Turkey. A long chain of intermediaries, national barriers and predominantly manual workflows adversely affect participation and representation of shareholders in general meetings around the world. International practices, standards and regulations together depict the features of a seamless and cost efficient model in general meeting processes. The study concludes that the new model, which was implemented by Merkezi Kayıt Kuruluşu A.Ş. (MKK), provides an ideal platform for the exercise of managerial rights in Turkey.
\end{abstract}

Keywords: corporate governance, electronic general meetings, central securities depositories, shareholder activism, electronic voting, proxy voting, investor relations. Jel Codes: G34, G38

\section{Elektronik Genel Kurul Toplantıları Türkiye'de Hissedar Haklarının Kullanımını Nasıl Etkiledi? : Türk Modeli'nin Uluslararası Standartlar ve Düzenlemeler Işı̆̆ında Analizi}

\section{Özet}

Bu çalışma, elektronik genel kurul sisteminin Türkiye'de uygulamaya alınmasının hissedar haklarının kullanımına olan etkilerini ele almaktadır. Uzun aracı zinciri, yerel mevzuata dair engeller ve ilgili iş akışlarında otomasyon eksiği gibi faktörler hissedarların genel kurul toplantılarına katılımını ve temsilini tüm dünyada olumsuz etkilemektedir. Uluslararası uygulamalar, standartlar ve düzenlemeler genel kurul toplantılarılla ilgili süreçlerin etkin ve düşük maliyetli gerçekleştirilmesine yönelik bir modelin ana hatlarını çizmektedir. Çalışma, Türkiye'de Merkezi Kayıt Kuruluşu A.Ş. (MKK) tarafından geliştirilip uygulamaya sunulan elektronik genel kurul modelinin hissedarların yönetim haklarını kullanmalarında önemli yararlar sağladığını ortaya koymaktadır.

\footnotetext{
* Yakup Ergincan is an Associate Professor, CEO and Board Member of Merkezi Kayıt Kurulu A.Ş., Süzer Plaza, No:6, Kat:3, 34367, Elmadağ, Șişli, Istanbul, Turkey. E-mail: yakup.ergincan@mkk.com.tr

** Bora Karaağaçlı is a Senior Specialist at Merkezi Kayıt Kurulu A.Ş., Süzer Plaza No:6, Kat:3, 34367, Elmadağ, Şişli, Istanbul, Turkey. E-mail: bora.karaagacli@mkk.com.tr
} 
7 he quality of corporate governance mechanisms on which shareholders' incentives rely depends on the way General Meeting (GM) participation is exercised. GM processes are becoming more complicated and costly for investors, with the increasing institutionalization and globalization of share ownership. Financial cross border services typically involve a long chain of intermediaries, and with additional barriers such as national laws that restrict electronic voting and market practices such as share blocking, this exacerbates the complexity of related procedures. Furthermore, manual workflows and non-automated processes in the exercise of shareholder rights increasingly create inefficiencies for issuers, intermediary institutions and investors.

In an ideal corporate actions management model, the source of information, issuer entities and their agents should have direct links to the system used by shareholders and their agents. This model would enable issuers to make GM related notifications sufficiently timely to allow all parties (i.e. custodians, shareholders and their agents) access to the flow and therefore to process and respond. Core GM processes such as issuer notifications, shareholder registrations, meeting day arrangements, proxy assignments and voting through a centralized and secure electronic platform can enable organizations and investors to work more productively, efficiently, consistently and securely within tight deadlines.

In this regard, Central Securities Depositories (CSDs), being the central data warehouses for capital markets that maintain securities accounts at the top tier level of the holding chain, are good candidates for operating platforms for corporate actions and GM processes. In particular, CSDs that operate direct account holding systems allowing segregation of accounts at the level of beneficial owners can remove complexities affecting the way in which shareholders exercise their rights. Intermediary institutions, banks and issuers are generally members of CSDs and this proximity allows these institutions to develop services for the exercise of financial and managerial rights by shareholders. ${ }^{[1]}$

This paper proposes the Turkish model, a single electronic platform (Electronic General Meeting System, "e-GEM”), which was developed by Merkezi Kayıt Kuruluşu A.Ş., the Central Securities Depository (CSD) of Turkey, as an ideal solution to the growing inefficiencies and costs in all GM process management chain that are faced by companies and shareholders. In the first part of the paper, we will outline the global framework for best practices and principles in management of GM processes and exercise of shareholder rights.

In the remaining parts, we will provide a review of the new Turkish model for GM process management and present the impacts it has had on corporate governance practices in Turkey since the October 2012 launch date. All in all, the paper introduces a nearly optimal system for GM processes that can be adapted by regulatory institutions, stock exchanges, CSDs and other capital market service providers around the world.

[1] It is worth noting that, even in CSDs that operate beneficial owner based account systems, investors can not be direct participants at CSDs. Investor accounts are usually operated by intermediary institutions that are hence called "account operators." 


\section{Global Initiatives Regarding General Meetings}

GM processes that allow efficient and transparent exercise of ownership rights are fundamental parts of modern corporate governance practices. However, such fully efficient systems rarely exist in any market in the world today, and the current state of market practices concerning GM operations hampers implementation of various public and private sector corporate governance initiatives.

The long chain of financial intermediaries (e.g. custodian banks, sub-custodian banks, voting agents, etc.) between companies and beneficial owners is the primary cause of the current complicated nature of GM operations. Each additional entity in the chain adversely affects the quality of information received from issuers and shortens the period in which a shareholder must decide on whether to exercise managerial rights. Apart from the obvious costs associated with the direct participation of foreign investors, the high number of shareholders residing in distant geographies adversely affects shareholder participation in GMs even in local markets (Kobler, 1998: 673). A clustering of meeting dates on certain months of the year in some local markets, and problems related to an effective distribution of issuer announcements such as meeting convocations further reduce the number of shareholder attendances at GMs. Low shareholder participation in turn gives rise to a preferential treatment of some shareholders, a practice which usually leads to the dominance of minority shareholders' decisions on company matters that are voted during GMs.

As the number of intermediaries increase, the link between companies and beneficial owners disappears. This problem is accentuated by national market practices that allow for nominee share holding structures, a common structure for many of the developed markets in the world. Investor holdings pooled in single nominee accounts, generally in the name of sub-custodians, make it nearly impossible to identify shareholders that possess managerial rights. Nominee accounts further complicate the voting process by restricting nominees (legal persons) to cast a single global vote on meeting agenda items irrespective of the individual decisions of shareholders who hold securities in those accounts. A sound corporate governance mechanism in this structure would require the shareholder to be physically present or represented at the meeting to cast a vote. However, in regard to the mainly institutional and cross-border nature of shareholdings, physical participance is far from being practical.

As a means to harmonize market practices and standards and to enforce their comprehensive implementation, international and public bodies began to take action during the last decade. In Europe, a directive (EU Shareholder Rights Directive) was enacted in 2007 to regulate the exercise of shareholder voting. Recent initiatives by international organizations in this respect include corporate governance principles that were issued by the Organisation for Economic Co-operation and Development's (OECD) and the International Corporate Governance Network (ICGN).

In this regulatory background, market standards in corporate actions operations, and in GM related operations in particular, were usually set up through voluntary initiatives, they being based on a general acceptance by market participants. However, market 
participants do not constitute a single body and as a result there have been various efforts in the past to generate a single set of GM operations standards around the world. The "Joint Working Group on General Meetings" (JWGGM), which was set up at the initiation of the European Commission to draft a single set of standards based on GM related processes in Europe, is an example of regional efforts. At the global level, the International Securities Services Association (ISSA) gathered national and regional standards into a single document and issued the "Global Principles for Corporate Actions and Proxy Voting" as a framework for issuers, intermediary institutions, industry associations, financial market infrastructures and regulators to support the implementation of best practices in national markets.

Before going into detail on the new Turkish practices for GM process management, a survey of recent developments in these initiatives will be provided to illustrate the properties of an ideal global model for GM related operations.

The EU Shareholder Rights Directive (2007) introduced a model for better corporate governance practices in EU member states. The directive primarily aims to resolve the costly and time-consuming nature of the flow of GM processes due to the involvement of a high number of intermediaries between issuers and end investors. It defines various standards that were further studied and harmonized by working bodies both at the European and the international level. These standards include minimum lengths of time for the exercise of rights, the nature of information to be delivered by issuers and the removal of obstacles to the exercise of shareholder rights to enhance corporate governance in listed companies. ${ }^{[2]}$

In the context of increasing cross-border investments, intermediaries are often subject to different legislations that affect the practical exercise of rights granted by company laws. The intermediated nature of the relation between issuers and investors makes the flow of information more complex and time-consuming. Several barriers to voting exist especially in cross-border voting schemes, since foreign institutional investors are prevailing in most markets (OECD, 2011: 52).

The EU member states are required to make necessary regulations in the context of the principles stipulated under the directive. The said principles are: equal treatment of shareholders, timely notification of shareholders, provision of electronic attendance at GMs, establishing means to assign proxies, enabling communication between companies and shareholders, and providing access to voting results.

According to the directive, the notice of attendance at GMs should be delivered by companies at least 21 days before the meeting. However, companies may decide to send convocation notices 14 days before a meeting when electronic attendance means are provided. The numbers regarding total shares and votes as well as share kinds, draft resolutions and proxy forms should also be issued together with the notice in case they are not directly sent to shareholders.

The directive further states that electronic attendance at GMs should not be restricted by national laws, whereas limitations regarding ID authentication and security are accepted as long as they are proportionate and compulsory. Similarly, shareholders' right to submit queries can only be limited by ID authentications, a smooth running of GM 
processes, the prevention of a disclosure of company secrets, and the protection of company interests. It is possible to give a sole response to questions on the same matter and a question may be deemed to be answered if the response is already published on the company web site.

Proxy voting was accepted in the directive as the most convenient way of voting for the investors who can not attend GMs due to geographical reasons. EU member states are free to regulate the number of the proxies a shareholder is allowed to assign for a GM. However, assignment of more than one proxy for shares kept in different accounts should be allowed. Shareholders must be allowed to assign proxies via electronic means, and at least one method to do so must be provided.

Disclosure of meeting results is considered an important component of GM procedures, and hence it is regulated under the directive. According to the directive, voting results should be published via the company web site no later than the 15 th day following the meeting date.

Another important change brought about by the directive is the removal of the EUwide system of share blockage. Share blockage was a market practice in ID authentications as an alternative to the record date system that is accepted in developed markets today. In this practice, the shareholders who intend to attend GMs were obligated to block their shares several days before a meeting. In essence, the practice prevented shareholders who wanted to trade their shares from attending GMs. The share blockage system is abolished with Article 7 of the directive, and the identification of beneficial owner shareholders is now legally required to be undertaken according to ownership status on record dates.

The Market Standards for General Meetings (2010), which was drafted by the Joint Working Group on General Meetings ${ }^{[2]}$ (JWGGM), primarily aims to dismantle the Giovannini Barrier 3. ${ }^{[3]}$ The barrier referred to difficulties faced by shareholders in EU cross-border exercises of managerial rights, and particularly, to the inefficient manual processes involved in GM related operations. The European level standards, which were endorsed by all market constitutiencies by July 2010, aimed to harmonize and streamline GM related operations in member countries within the framework of regulations such as the Shareholders Directive. Gap analyses were undertaken by countries and Market Implementation Groups (MIGs) were formed to monitor the level of compliance in each country.

Above all, the standards point to the need for "cost-efficient and effective (as to cost, time, and security)" flows of information between all parties involved. Shareholders should be informed and updated by issuers "by close of business day" of any

[2] JWGGM is an experts group initiated by the European Commission at the end of 2005.

[3] One of the EU Commission initiatives aimed at the integration of capital markets was the creation of a group of experts known as the Giovannini Group. 15 barriers that prevent efficient cross-border clearing and settlement of securities in the EU were identified by two reports issued by the Group in 2001 and 2003. Barrier 3 concerned harmonization of corporate actions practices, including GM processes, in member states. For a review of the two reports see CESAME, "Solving the industry Giovannini Barriers to post-trading within the EU," 28 November 2008. 
information related to a meeting. Electronic systems should be used for distribution of information, which should take place in globally accepted message formats (i.e. ISO standards), and where possible by straight-through-processes (STP). The narrative text area of these messages should be written in English for the use of foreign investors.

CSDs and intermediaries such as local custodians stand between issuers and shareholders as the parties to direct information from issuers to beneficial owners within one business day from the settlement of a transaction. Although it is accepted that there might be many number of intermediaries in the chain, information sourced from issuers should remain "unaltered" in its communication to shareholders.

As stated in the Shareholders Directive, share blockage practice should be removed in shareholder identification for meeting participation and voting. Investors' entitlements for managerial rights should be determined by close of business at record date by using the beneficial owner records at CSDs and issuer books. Shareholders should be able to declare their participation status (attendance in person or through a proxy) to intermediaries up to four or five days before a meeting. Issuers should receive these declarations two or three days before a meeting.

All in all, electronic systems, which could be established by CSDs, were recommended by the standards to implement the automatic flow of information down the process chain and to enable meeting participation.

Global Principles for Corporate Actions and Proxy Voting (2012) of ISSA working group on corporate actions, consolidated ongoing best practice and harmonization initiatives around the world and issued a single market standards document that also included best practices for GM related operations. The document states that information flow sourced from issuers should be in a digitized form in adherence to ISO standards, and should take place "not less than five to fifteen business days" before a key date in an ideal GM operations model (ISSA, 2012: 12). Implementation of STP in processes starting with communication of notifications is one of the fundamental aspects of this model.

ISSA acknowledges the fact that implementing the digital flow of information has a limited success around the world due to a lack of regulations mandating issuers and agents to send GM related data in suitable electronic formats (ISSA, 2013: 3). Digitization of information at the source, that is from the issuer, is regarded as crucial for the electronic communication of GM related data in an efficient, secure, complete and correct way. Considering significant financial risks involved in the manual entry of data in the process chain, a central utility for the digital flow of information was recommended as an ideal platform.

Market infrastructures, CSDs in particular, were identified as having primary roles as "centralizing agents" in GM processes. According to the standards, these institutions should ensure the effective and timely flow back and forth between issuer companies and shareholders of information such as meeting announcements, voting instructions, confirmations and meeting results. Meeting related documents such as prospectuses should also be made available before meetings through public websites (ISSA, 2012: 7). 
The standards assign the task of establishing electronic voting in local markets to issuer companies. Electronic voting should not be confined to manual entry of votes by shareholders (or their agents) into a "web platform" owned by issuers (or their agents). Shareholders should be able to vote and assign proxies through electronic means using ISO formatted messages, and issuers should confirm the receipt of votes in a timely manner through the same platforms. Post-meeting information such as resolution and voting outcomes should also be made available for shareholders through public websites where possible (ISSA, 2012: 13).

The OECD's Principles of Corporate Governance (2004) include regulations related to shareholders' rights under the sections II and III. Section II with the title, "The Rights of Shareholders and Key Ownership Functions," (OECD, 2004: 32) defines shareholder rights as basic rights. It is stipulated under principle II.A that the basic rights should include the right to use secure methods of ownership registration, to convey or transfer shares, to obtain relevant and material information on the company on a timely and regular basis, to elect and remove members of the board, to share in the profits of the corporation, and to participate and vote in GMs. The right to participate and vote in GMs is treated in detail under principle II.C. According to this principle, shareholders should have the right to effectively attend and vote in GMs. Moreover, they should be informed of the rules, including voting procedures that govern GMs; they should be provided with the opportunity to ask questions, place items on the meeting agenda, and they should be furnished with sufficient and timely information concerning the date, location and agenda of meetings, as well as full and timely information regarding the issues to be decided at the meeting. Principle II.C.3 is related to proxy voting and states that shareholders should be able to vote in person or in absentia, and equal effect should be given to votes whether cast in person or in absentia.

Section III (OECD, 2004: 40) is titled "The Equitable Treatment of Shareholders." A component of the equitable treatment of shareholders is defined as removing the impediments to cross-border voting. Furthermore, according to principle III.A.5, which is closely related to the principle III.A.4, processes and procedures for GMs should allow for equitable treatment of all shareholders, and company procedures should not make it unduly difficult or expensive to cast votes.

The OECD Principles were undergoing a review at the time of writing this article in order to reflect recent changes in capital markets. The draft review of the OECD Principles of Corporate Governance ${ }^{[4]}$ (2014) gives a greater weight to the use of electronic methods in GM processes. In the revised principle II.C.2 electronic platforms are recommended for the delivery of proxy materials. In principle II.C.5, the usage of secure electronic media is recommended to support shareholder participation in GMs through proxies. Furthermore, in section III.A paragraph 47, disclosure of voting records is given as good market practice.

ICGN Global Governance Principles (2014), drafted by ICGN's "Shareholder Rights Committee," focus on improving voting processes in the world. The commit-

[4] The final version of the Principles is planned to be publish by the OECD in 2015. Please refer to http://www.oecd.org/ $\mathrm{daf} / \mathrm{ca} /$ public-consultation-review-oecd-principles-of-corporate-governance.htm for the latest status of the document. 
tee identified operational weaknesses, transparency and verifiability issues regarding voting practices and made suggestions on removing obstacles to efficient cross-border voting in particular.

There can be inconsistencies between the meeting agenda issued by companies ("golden copy") and the agenda received by investors due to the great number of intermediaries between the parties. These intermediaries are usually responsible for the translation of the agenda and the aggregation of agenda items. Any information omitted or mishandled by the intermediaries can have serious consequences in the conveyance of complete and correct information to shareholders. In this regard, electronic methods for the issuance of golden copy data should be used for the direct access of shareholders.

According to the ICGN recommendations, GM agenda, along with information such as the date and location of a meeting, should be made available to shareholders through company websites or any other electronic means at least one month before the meeting (ICGN 2014: 19). The committee recommends direct delivery of meeting notices by companies to CSDs using messages in standard formats (i.e. ISO formats). Share blocking or any restrictions regarding share holdings should also be abolished.

A reliable vote confirmation system is another requirement of an efficient voting system. In this regard, confirmations on votes cast in person or through proxies should be delivered to shareholders promptly. Outcomes of the votes and voting results per agenda item should be recorded and made available for shareholders' access. All in all, ICGN recommendations focus on electronic means for dissemination of meeting related documents and information and for electronic voting as best practices.

\section{Properties of an Ideal System for General Meeting Processes}

All the principles and standards combined aims to remove difficulties investors face in exercising managerial rights, especially when their securities are held cross-border. Services provided to local and international investors should be at the same level in order to enhance participation in GMs as a precondition for improving the level of corporate governance practices. Other properties can be summarized in four categories as follows:

1. GM processes are among the types of corporate actions operations that involve a flow of information in both directions (i.e. from issuer to intermediary/beneficial owner and from intermediary/beneficial owner to issuer). An issuer, with the responsibility to provide correct and complete information and documentation should provide the source information and related notifications via an intermediary, a CSD or another single platform ${ }^{[5]}$ all the way to beneficial owners in a secure and timely manner. Shareholders in turn should have the capability of registering their votes in a timely and cost efficient way. In case a proxy is assigned by a shareholder, confirmation of the registered votes should also be executed preferably using the same communication channel.

[5] Considering the market traditions of clustering GMs in certain months of the year, quick and complete delivery of information has an utmost importance. In that regard, a single platform for all GMs would be the best alternative. 
2. Practice of securities freezes should be eliminated in shareholder identification. Electronic methods that would also be utilized for communication within operational deadlines ${ }^{[6]}$ and remote voting purposes should be introduced. Flow of information should take place through a secure electronic environment ${ }^{[7]}$ which would also facilitate STP from issuer to beneficial owner by using global industry standards and formats. The platform should aim at ensuring efficiency in GM related processes in order to reduce operational costs and risks.

3. Shareholders should be able to assign proxies and vote in a timely and cost effective manner. Since voting is not the primary mechanism for shareholder engagement, an ideal model of GM management system should enable monitoring of company management in an efficient way, such as by getting in direct communication with company representatives.

4. An ideal operations model should also provide fast and easy access to meeting results following the conclusion of GMs. Shareholders should be able to receive all relevant information that flows from companies regarding GMs. The model should establish better communication between companies and investors to ensure more informed exercising of managerial rights and thus improving corporate governance and investor protection.

\section{Electronic General Meeting Model in Turkey - Regulatory Background}

Management of GM related operations builds on a sound legal framework that directly affect shareholder participation in a country, and hence the level of corporate governance. Market practices designed on such a regulatory background should be able to bridge the gap between issuers and shareholders. Turkey is a good example for this phased approach where regulatory reforms initiated new market practices in GM processes.

The major obstacle affecting corporate democracy in Turkey was the low level of shareholder participation to GMs. Low participation levels were aggravated by the rising share of foreign, mostly institutional, investors in the shareownersip structure of Turkish publicly traded companies ${ }^{[8]}$ It was clear that a regulatory reform was needed in order to tackle this issue once and for all.

The first major reform concerning GM operations in Turkey came with the new Turkish Commercial Code (TCC 6102). The Code, effective on 1 July 2012, brought about drastic changes in GM operations. The most significant of these changes were giving electronic participation the same legal basis as participation in physical meetings and mandating that all listed companies convene electronic GMs concurrently with physically present meetings. Hence, Turkey became the first country in the world to

\footnotetext{
[6] As an example to these deadlines, standards recommend that companies should send GM related information to shareholders at least 21 days before a meeting. 'Record dates,' usually 2 days before a meeting, should also be implemented in national markets for correct identification of right owners.

[7] This environment should ideally make use of a digital signature framework.

${ }^{[8]}$ According to MKK records, the share of foreign ownership in free float shares was $64 \%$ as of end 2014.
} 
legally mandate usage of electronic platforms for GM operations ${ }^{[9]}$ (Kelleher, 2012). Article 1527 of the Code paved the way for direct shareholder participation in GMs, introducing real time interaction of shareholders and company representatives, as well as electronic participation and electronic voting. Furthermore, the market practice of freezing shareholdings before GMs was abolished in Articles 415 \& 417. Shareholders' lists containing information on shareholders or their proxies, that could be obtained from MKK system one day before the meeting, became the new standard for shareholder identification.

MKK, as a CSD that has all listed issuer companies as its participants and as the operator of a beneficial owner based depository system, was deemed to be an ideal institution in establishing a single electronic platform for GM operations. The shareholding records held at MKK system constituted the most up-to-date stock ledgers for floating and non-floating shares in Turkey. As the identification of shareholders was easier in this system, the exercise of rights by investors could be undertaken in a less complicated and more direct way. Issuers could also easily report the number of votes that were to be cast at GMs.

MKK's investor based account holding system was also ideal for establishing a model that would allow straight through processing of GM related operations. The resulting efficiency is important in determining beneficial ownership of shares and enabling a direct communication channel between issuers and shareholders since all listed companies have a legal obligation to become MKK members. The CSD holds, besides ownership data, contact information such as e-mail addresses and mobile phone numbers for all investors in Turkey. Utilizing these data has enabled MKK to create a platform that directly connects shareholders and issuer companies for all GM related processes beginning from the distribution of pre-meeting information.

MKK's central role had indeed previously been stated in the Istanbul International Financial Center project's strategy document of 2009, which had assigned the institution for the task No. 49, the "Exercise of dematerialized ownership rights on electronic environment," as the responsible entity. However, only after the enactment of the new Capital Market Law (CML 6362) on 30 December 2012 did this assignment gain a regulatory backing. Article 30 of the law ruled that electronic participation in GMs of publicly traded companies should be carried out through the platform that would be established by MKK.

The laws and subsequent secondary regulations furthermore introduced a pure record date system for identification of shareholders and institutional representation for the collective exercise of voting rights. Moreover, important dates for GM processes were harmonized with international standards. Besides determination of the record date (GMD-1 until 23:59 pm), posting of meeting convocations on company websites and the trade registry gazette was mandated to take place three weeks before the meeting date. Delivery of meeting documents such as audit reports had also to be undertaken at least 15 days before a meeting according to the new regulations.

[9] Although electronic platforms are widely used in the USA and Europe, their usage has never been made a market practice. As a result, most of the GM related operations in advanced markets are still handled manually. 
A fundamental feature of the electronic platform that ensures information security and ease of access is the usage of electronic signatures which have the same legal effect as hand-written signatures. The e-Signature Law (ESL No. 5070) had permitted wide usage of electronic or mobile signatures that contain personal ID data in online services years before the introduction of an electronic platform for GMs. This regulatory framework further allowed MKK to establish a system which completely changed the whole process chain in GM operations.

CSDs' involvement in GM related services is in fact a recent, yet not very wide, trend in other countries too. VP Securities A/S, the Danish CSD which also operates a beneficial owner-based account structure, began providing electronic voting facilities following the change in the Danish Code of Commerce in 2003. Although the legal changes allowed convening of virtual-only GMs in the country, a hybrid structure where e-voting is applied at physical GMs is in use at the moment. ${ }^{[10]}$ Apart from hybrid models, virtual-only GM platforms were introduced in some countries like the USA by third party service providers. On the other hand, virtual-only GMs were shunned by shareholders because of the limited communication capabilities provided by those platforms (Ergincan ve Yayla, 2011: 14-15). The Turkish model is however unique as a system that encompasses all GM related operations (for both physical and virtual meetings) from automatic notifications to e-voting, and as a communication platform between shareholders and companies. e-GEM operations and their effects on corporate governance practices in Turkey will be examined in the next sections.

\section{The Electronic General Meeting System (e-GEM) and the New GM Process Management Chain in Turkey}

The first and most comprehensive study on electronic general meetings in Turkey was "Corporate Governance: Status in Turkey and Suggestions for Improvement" by Yakup Ergincan and Osman Gürbüz (2004: 91-102). In this book, the authors discuss in detail how to conduct general meetings through the web and establish a central electronic platform for general meeting related operations, and point out the possible economic benefits that would arise with such a platform.

The new model was further defined by Ergincan in its improved form as "Mobile Corporate Governance" (Ergincan, 2011: 181) which encompasses a high degree of communication between shareholders and companies through electronic media. The GM process chain on the electronic platform to be designed by MKK began with the automatic notification of shareholders through channels such as SMS and e-mail messages before GMs. The platform would also enable remote participation, representation, real time electronic voting and communication and post-meeting information sharing.

The e-GEM project was started in November 2011 and included the responsibility assigned to MKK under the Istanbul International Financial Center project. The system was launched in October 2012 following the enactment of the new TCC. e-GEM represents

${ }^{[10]}$ For the VPS e-voter ${ }^{\circledR}$ service please refer to https://www.vp.dk/en/Services/Investor-Services/Meeting-Services/evoter 
the "virtual general assembly" method as opposed to the "online participated presence" method as it aims to bring all shareholders onto a single electronic platform through which the whole GM process is managed, including remote participation (Ergincan, 2011: 189). Nevertheless, e-GEM did not bring about an electronic-only GM practice in Turkey. The current system in Turkey is a hybrid model that allows both in-person and electronic attendance.

e-GEM aims, first and foremost, to raise the level of corporate governance in Turkey to the level set by global regulations, industry standards and best practices. The system achieved this by introducing a platform for borderless participation for GM related processes. In fact, e-GEM established a much more effective system by connecting issuer companies directly with shareholders, utilizing the direct account holding structure operated by MKK. As a system that enables two-way direct communication between shareholders and companies, e-GEM goes beyond the requirements of global standards and best practices in corporate governance. (Ararat and Eroğlu, 2012)

A general limitation of implementing full STP in GM processes, as recommended in international standards, is that issuers are usually not the first source of GM related information. Due to this fact, information sourced from issuers can have different formats. This "multi format" problem is usually solved with high operational costs by scrubbing corporate data from different sources. In this limited model issuers have no ability to reach their shareholders directly in a timely and complete manner. The legal framework and the integraton of MKK's Central Dematerialized System (CDS) with the Public Disclosure Platform ${ }^{[11]}$ (PDP), the primary source of information on listed companies in Turkey, paved the way for establishing a GM process management model in Turkey, unprecedented in scope and application in the world. The integration of two systems and the transfer of PDP management to MKK facilitated STP in distribution of GM related information.

Operations before the GM date begin with automatic notifications sent by issuers directly to shareholders through the PDP, which is one of the most crucial components of the GM management model in Turkey. In operation since June 2009, the PDP enables issuer companies to post their financial statements, disclose material events, and make corporate action notifications and other company announcements directly for the use of investors in a reliable and secure manner. The integration of this platform with e-GEM enabled issuers to send GM related information such as meeting dates to shareholders directly and without any manual intervention, once they post them on the PDP. Digitally signed convocation letters, proxy letters and company documents that are related to GMs, such as meeting agenda, proxy samples, amendment texts, etc. can also be uploaded on e-GEM by companies. This initiates instant notification of shareholders and other investors that are interested in receiving information on the company through

\footnotetext{
${ }^{[11]}$ Operations of PDP were transferred from Borsa Istanbul to MKK on 17 March 2014. This management model created further efficiency in development of new projects such as PDP 4.0 that will facilitate direct utilization of PDP data in MKK services. PDP 4.0 will also enable usage of XBRL (Extensible Business Reporting Language) in distribution of corporate data and will implement a fully bilingual (Turkish \& English) platform. The project is planned to be finalized in Q2 2016.
} 
SMS ${ }^{[12]}$ e-mail and SWIFT messages in internationally accepted formats. Interested parties are also notified on any changes in information and documents that are posted on the system. Shareholders that receive these notifications can declare their attendance (electronic or physical) or assign a proxy using the system by entering their IDs until one day before the meeting. Proxies are in turn notified through e-mail or SMS messages when an assignment takes place and they can attend the meeting physically or through e-GEM by registering with the system.

One of the most significant improvements in GM operations in Turkey was the removal of the practice of blocking shareholder securities before a meeting. A blockage mechanism was previously applied to identify shareholders who hold bearer shares three days before GMs and who have the right to vote at meetings. This practice was also carried out to prevent these rights holders from selling their bearer shares ${ }^{[13]}$ until the end of meetings. The legacy practice for bearer shares became obsolete with the dematerialization of both registered and bearer shares and the increasing use of electronic systems in GM management that allowed automatic identification of beneficial owners by issuer companies. In the new practice, lists of shareholders that own securities carrying managerial rights are received by issuer companies from the e-GEM system one day before the meeting. The list of attendants for both physical and electronic meetings can be created in the legally required format by companies through e-GEM.

Another improvement in pre-GM operations came in proxy voting processes for foreign shareholders. In the previous system, local custodians that usually represent foreign institutional investors in GMs were undertaking cumbersome manual processes to be able to vote as proxies on behalf of these investors. In fact, the complicated background procedures, such as the inefficient flow of information on beneficial owners and legally required documents between foreign shareholders, their agents and the local custodians were the main factors limiting foreign shareholders' participation to GMs in Turkey. The traditional paper-based process required written and undersigned documents, whereas e-GEM makes use of the electronic signature framework. Delivery of proxy materials through the system removes preparation and sending $\operatorname{costs}^{[14]}$ and ensures that shareholders receive the required documents directly. The system creates a further efficiency by allowing shareholders to send the materials back through the same platform. Moreover, shareholders that have voting rights can register their votes in advance of the meeting through their proxies.

Lists of attendants that are received by issuer companies one day before the meeting include IDs of proxies. This practice removes the need to submit any written document (e.g. power of attorney) for GM attendance for the proxies who are assigned through e-GEM. In fact, the electronic signature framework used in accessing the system also disposes of any other previously required processes for the identification of sharehold-

\footnotetext{
${ }^{[12]}$ Only applicable for real person investors.

${ }^{[13]}$ Registered shares were exempt from this practice as beneficial holders of these shares were registered in company books.

${ }^{[14]}$ Although there is no study carried out comparing mail delivery costs with e-voting in Turkey a similar comparison was made for the Australian case (Alcock et al., 2006). The study estimated that electronic voting costs $\$ 0.03$ per shareholder, while proxy voting through mail delivery costs up to $\$ 0.37$.
} 
ers and proxies. Shareholders can give a general mandate to their proxies or they can choose to send separate instructions on each agenda item. In case such voting restrictions are set by the shareholder, e-GEM automatically sends the pre-determined votes when the proxy logs on to the system. In this regard, the shareholder is protected against any inconsistent votes cast by the proxy.

According to the new regulations, shareholders can send, change or revoke their instructions one day before the meeting date. Voting instructions that will be utilized by proxies are sent by shareholders to the system observing the same timeframe. e-GEM also supports usage of multiple voting methods such as split voting and partial voting with the ability to restrict proxies on certain voting items. This feature of the system creates significant efficiencies particularly for foreign institutional investors who enter voting instructions on behalf of many beneficial owners, and hence allows effective individual representation at GMs.

General meeting day operations, including participation, voting and real-time communication are the main components of e-GEM. The system allows concurrent attendance at multiple GMs by the same user, by establishing a single point of access for shareholders. Shareholders and assigned proxies can attend meetings simultaneously conducted on the same day on e-GEM. Shareholders who do not attend meetings in person can give instructions to their proxies on e-GEM during the flow of the meeting. This ensures proxies acting solely in accordance with investor preferences and recording these on the electronic platform. Furthermore, pre-registered votes that were entered before a GM can be changed during the meeting if a shareholder logs on to e-GEM and attends the meeting electronically.

During a meeting, shareholders have several options for casting their votes. Voting instructions that were saved before the meeting are automatically sent by the system at the start of the voting time period ${ }^{[15]}$ per agenda item. Shareholders can update their votes during voting time; otherwise the pre-saved votes are automatically confirmed.

The exercise of managerial rights is an important aspect of corporate governance. However, voting per se does not guarantee a good level of productive engagement between companies and shareholders. Indeed, GMs have always been a platform for issuer companies to provide information to their shareholders on the latest developments in the management and future outlook of a company. Traditionally, investors interact with company representatives at GMs by asking questions in addition to voting on matters on the agenda. However, with the increasing involvement of institutional investors in company management, the direct communication between shareholders and company boards has become an issue.

e-GEM, besides its main functions as an online system for electronic attendance, e-voting and e-proxy voting, has created a communication platform where shareholders or their proxies can watch the live broadcast of the physical meeting and monitor the meeting flow on their customized meeting screens. In this regard, the Turkish model for GM process management introduced concurrent electronic voting and communication

${ }^{[15]}$ Voting time period is usually 2 minutes in Turkey. 
between all parties for the first time in the world (Keser Berber, 2012: 15). Shareholders have the opportunity to express their opinions and make suggestions on a real time basis on the agenda items that are discussed during the meeting. ${ }^{[16]}$ They can have their say on corporate decisions such as amendments to governing documents of the company, remunerations of senior managers, or authorization of additional shares, and can place items on the meeting agenda or propose resolutions. Following the approval of the meeting agenda, attendees cast their votes electronically or physically on a simultaneous basis.

Votes that are cast through e-GEM are reflected on the system screen that is used by the meeting chairman. Physical and electronic votes that make use of multiple methods such as partial and split voting are combined by the chairman and recorded in minutes of the meeting. Shareholders are notified through SMS/e-mail messages on all the operations performed during a meeting.

Post-GM operations were drastically improved with the introduction of an electronic system in the way the related parties access GM related information and documents. In no later than 15 days, meeting information and voting reports are instantly communicated to all participants via e-GEM, and vote confirmations are available to any requesting parties with the new market practice in compliance with international standards and principles. The GM process chain which begins with automatic issuer notifications ends with a final notification made by the issuer at the end of the meeting. This notification is sent by $6 \mathrm{pm}$ of the closing day or, for GMs closing later than that, by 9 am of the following day. Meeting information and voting results are instantly communicated through SMS, e-mail and SWIFT messages uploaded by companies on e-GEM.

Archiving and availability of information and documents related to past GMs are usually costly and cumbersome in traditional GMs (Yayla, 2013: 54). e-GEM provided the opportunity to disclose and archive GM related information and documents, such as meeting list of attendees, meeting resolutions, meeting minutes, voting results and audio-visual records on a secure electronic environment for both physical and electronic GMs. Post-GM information can also be reported by users according to various criteria, and in multiple languages. Easy access to information such as the results of proxy votes for shareholders, and access to voting policies for companies and analysts help them in their evaluations and decisions. Companies can report information including votes cast on the beneficial owner basis, opposition declarations, shareholder queries, voting ratios per agenda items, etc. which altogether help improve the investor relations strategies of companies.

All in all, e-GEM provides a forum for shareholders to communicate in real time with each other as well as with issuer representatives. Live communication between shareholders and company representatives through an online forum, before, during and after a meeting, not only creates goodwill for all parties but also improves the level of corporate democracy by enabling active participation of shareholders in corporate decisions.

${ }^{[16]}$ Number of suggestions are restricted to two suggestions per agenda item to prevent any suggestions hampering the flow of a meeting. The length of suggestions and questions are further limited to 600 words. 


\section{The Impact of the Introduction of e-GEM on the Exercise of Rights by Shareholders in Turkey}

Improvements in corporate governance practices in Turkey that are brought about by eGEM are reflected in the increasing number of GM participations both for domestic and foreign shareholders. Although the new regulation mandated convening electronic GMs only for listed companies, following e-GEM's launch in October 2012 the first GM that took place using the platform was by that of an unlisted company. Since the launch of the system in October 2012, 346 companies have conducted their GMs ${ }^{[17]}$ through e-GEM, with the total number of electronic GMs reaching 749 in the two years of the system's operation. Changes in the number of shareholder participations in ordinary GMs since the go-live date are depicted in Table 1. The total number of GM participations was 20,701, corresponding to a $127 \%$ increase in 2014 over that of $2011 . .^{[18]}$ The increase in the total number of GM participants is $146 \%$ since e-GEM became operational.

Table 1

\begin{tabular}{ccccccc}
\hline Year & $\begin{array}{c}\text { Physical GM } \\
\text { Participation }\end{array}$ & $\begin{array}{c}\text { Electronic GM } \\
\text { Participation }\end{array}$ & $\begin{array}{c}\text { Total } \\
\text { Participation }\end{array}$ & $\begin{array}{c}\text { Rate of Increase } \\
\text { (Physical GMs) }\end{array}$ & $\begin{array}{c}\text { Rate of } \\
\text { Increase } \\
\text { (Electronic } \\
\text { GMs) }\end{array}$ & $\begin{array}{c}\text { Rate of } \\
\text { Increase } \\
\text { (Total) }\end{array}$ \\
\hline 2011 & 9,093 & - & $\mathbf{9 , 0 9 3}$ & - & - & - \\
\hline 2012 & 8,394 & $-*$ & $\mathbf{8 , 3 9 4}$ & $-8 \%$ & - & - \\
\hline 2013 & 6,339 & 13,464 & $\mathbf{1 9 , 8 0 3}$ & $-24 \%$ & - & $135 \%$ \\
\hline 2014 & 5,014 & 15,687 & $\mathbf{2 0 , 7 0 1}$ & $-21 \%$ & $16 \%$ & $4.5 \%$ \\
\hline
\end{tabular}

*Between 01.10.2012 and 31.12.2012, 94 shareholders participated in electronic GMs. This number was omitted in the calculation.

Statistics indicate that shareholders have shown their preference for electronic GM participation over physical participation. Although the total number of participations has gone up significantly, the number of physical participations in 2014 has decreased by $45 \%$ and $40 \%$ compared to 2011 and 2012 respectively. Moreover, the share of participations through e-GEM has reached 68\% and 76\% in 2013 and 2014 respectively. When only participations in ordinary GMs are taken into account, the total number of shareholders participating in meetings individually or through proxies reached 15,950 as of October 2014; corresponding to an increase of $133 \%$ and $69 \%$ in comparison to 2011 and 2012 respectively. These dramatic changes in shareholder participation in such a short time period justifies the regulatory reforms that aimed to raise the level of shareholder democracy in Turkey by setting up the legal framework for an electronic GM platform.

\footnotetext{
${ }^{[17]}$ The participation statistics provided in this study include ordinary and extraordinary GMs, and GMs of shareholders with preferential rights.

${ }^{[18]}$ In the following analyses it was assumed that all shareholders declaring their attendance before a meeting actually attended those meetings. In this regard, the actual numbers of participation in both physical and electronic GMs might be lower.
} 
An important factor behind the increase in the number of GM participations is reflected in the significant increase in foreign shareholder participation since the launch of e-GEM as depicted in Table 2. Based on those numbers, the number of foreign shareholder participants in ordinary $\mathrm{GMs}^{[19]}$ in Turkey has gone up by 490\% from 2011 to 2014. In addition to the increase in numbers, the share of foreign shareholder participation jumped from $33 \%$ in 2011 to $84 \%$ in 2014 . As shown in Table 3, foreign shareholders began to use e-GEM solely for GM participation instead of in person attendance. In $2014,98 \%$ of foreign shareholders used e-GEM for GM participation while $90 \%$ of domestic shareholders chose to be present at the meetings.

Table 2

\begin{tabular}{ccccc}
\hline Year & $\begin{array}{c}\text { Number of Domestic } \\
\text { Shareholders }\end{array}$ & $\begin{array}{c}\text { Number of Foreign } \\
\text { Shareholders }\end{array}$ & $\begin{array}{c}\text { Rate of Increase } \\
\text { (Domestic) }\end{array}$ & $\begin{array}{c}\text { Rate of Increase } \\
\text { (Foreign) }\end{array}$ \\
\hline 2011 & 4,557 & 2,227 & - & - \\
\hline 2012 & 6,901 & 2,524 & $51 \%$ & $11 \%$ \\
\hline 2013 & 2,581 & 11,893 & $-63 \%$ & $371 \%$ \\
\hline 2014 & 2,510 & 13,440 & $-3 \%$ & $13 \%$ \\
\hline
\end{tabular}

Table 3

\begin{tabular}{ccccc}
\hline Year & $\begin{array}{c}\text { Number of } \\
\text { Domestic Electronic } \\
\text { Participation }\end{array}$ & $\begin{array}{c}\text { Number of } \\
\text { Domestic Physical } \\
\text { Participation }\end{array}$ & $\begin{array}{c}\text { Number of } \\
\text { Foreign Electronic } \\
\text { Participation }\end{array}$ & $\begin{array}{c}\text { Number of } \\
\text { Foreign Physical } \\
\text { Participation }\end{array}$ \\
\hline 2011 & - & 4,557 & - & 2,277 \\
\hline 2012 & - & 6,901 & - & 2,524 \\
\hline 2013 & 190 & 2,391 & 10,591 & 1,302 \\
\hline 2014 & 245 & 2,265 & 13,113 & 327 \\
\hline
\end{tabular}

Considering the fact that foreign share ownership in Turkish public companies varies between 60 and $70 \%$ in the last 3 years, ${ }^{[20]}$ providing a single electronic platform for shareholders so that they could exercise their managerial rights remotely and efficiently was a major breakthrough in corporate governance practices in Turkey. The system also helped local custodian banks that act as proxy on behalf of foreign shareholders. A central electronic portal for management of all GM-related operations created efficiency in cost, time and human resource for these banks as foreign shareholders who are active in Turkey have residencies in more than 40 different countries. ${ }^{[21]}$ Electronic assignment of local custodians through e-GEM allows them to carry out GM operations for their clients and attend GMs without submitting power of attorney documents. Shareholders and custodian banks that act as proxies can receive instantenous notifications through

\footnotetext{
${ }^{[19]}$ For a sound analysis only number of GM participations to ordinary meetings were taken as the basis in the following section.

${ }^{[20]}$ MKK system data.

${ }^{[21]}$ In 2014 foreign shareholders from 49 different countries participated to GMs through e-GEM.
} 
SWIFT messages. They also have the ability to access all GM related information and documents before and after GMs in order to meet any local reporting requirements.

The increase in the number of institutional shareholder participations in GMs is also striking after the introduction of e-GEM. As depicted in Table 4, the participation of institutional investors, comprised mostly of foreign investors, went up by $342 \%$, whereas individual participations dropped by 45\% in the period from 2011 to 2014 . The share of institutional investors in GM participation increased from $46 \%$ to $87 \%$ in the same period. Furthermore, as shown in Table 5, the share of institutional investors participating in GMs through the electronic platform was $94 \%$.

Table 4

\begin{tabular}{ccccc}
\hline Year & $\begin{array}{c}\text { Number of Individual } \\
\text { Shareholders }\end{array}$ & $\begin{array}{c}\text { Number of Institutional } \\
\text { Shareholders }\end{array}$ & $\begin{array}{c}\text { Rate of Increase } \\
\text { (Individual) }\end{array}$ & $\begin{array}{c}\text { Rate of Increase } \\
\text { (Institutional) }\end{array}$ \\
\hline 2011 & 3,686 & 3,148 & - & - \\
\hline 2012 & 6,102 & 3,323 & $66 \%$ & $6 \%$ \\
\hline 2013 & 2,106 & 12,364 & $-65 \%$ & $272 \%$ \\
\hline 2014 & 2,043 & 13,907 & $-3 \%$ & $12 \%$ \\
\hline
\end{tabular}

Table 5

\begin{tabular}{ccccc}
\hline Year & $\begin{array}{c}\text { Number of } \\
\text { Individual Electronic } \\
\text { Participation }\end{array}$ & $\begin{array}{c}\text { Number of } \\
\text { Individual Physical } \\
\text { Participation }\end{array}$ & $\begin{array}{c}\text { Number of } \\
\text { Institutional } \\
\text { Electronic } \\
\text { Participation }\end{array}$ & $\begin{array}{c}\text { Number of } \\
\text { Institutional } \\
\text { Physical } \\
\text { Participation }\end{array}$ \\
\hline 2011 & - & 3,686 & - & 3,148 \\
\hline 2012 & - & 6,102 & - & 3,323 \\
\hline 2013 & 190 & 1,916 & 10,591 & 1,774 \\
\hline 2014 & 244 & 1,799 & 13,114 & 793 \\
\hline
\end{tabular}

The share of capital that was represented in ordinary GMs of 234 companies in our dataset reflects an interesting impact of electronic meetings. As depicted in Table 6, in 2014 , the ratio of capital represented at GMs to the total capital of companies increased by 3.65 and 3.35 points from the ratios in 2011 and 2012 respectively. These increases indicate that those shareholders who did not participate in GMs before the launch of e-GEM decided to do so in the following years. The Appendix to this paper gives a statistical analysis for the detection of normality in descriptive statistics.

Table 6

\begin{tabular}{lllllll}
\hline \multirow{2}{*}{ Yll } & $\begin{array}{l}\text { Physical } \\
\text { Participation/ } \\
\text { Capital (\%) }\end{array}$ & $\begin{array}{l}\text { Electronic } \\
\text { Participation// } \\
\text { Capital (\%) }\end{array}$ & $\begin{array}{l}\text { Total } \\
\text { Participation/ } \\
\text { Capital (\%) }\end{array}$ & $\begin{array}{l}\text { Rate of } \\
\text { Increase } \\
\text { (Physical) }\end{array}$ & $\begin{array}{l}\text { Rate of } \\
\text { Increase } \\
\text { (Electronic) }\end{array}$ & $\begin{array}{l}\text { Rate of } \\
\text { Increase } \\
\text { (Total) }\end{array}$ \\
\hline 2011 & 61.60 & - & 61.60 & - & - & - \\
\hline 2012 & 61.94 & - & 61.94 & 0.34 & - & 0.34 \\
\hline 2013 & 56.83 & 3.22 & 60.05 & -5.11 & - & -1.89 \\
\hline 2014 & 60.93 & 4.32 & 65.25 & 4.10 & 1.10 & 5.20 \\
\hline
\end{tabular}


The availability of simultaneous participation in multiple GMs through e-GEM was another reason behind the increasing participation. Statistically, around $50 \%$ of all meetings of publicly traded companies in Turkey are convened in March, while the maximum number of meetings on a single day was 33. ${ }^{[22]}$ These numbers depict how difficult it is for a shareholder to participate in more than one GM in a given year with a solely physical system.

e-GEM's communication platform function further contributed to the improvement of the level of corporate democracy by supporting direct shareholder activism. Shareholders sent 455 real-time queries/suggestions and 420 dissenting votes through e-GEM during the years covered by this study. The two-way interaction introduced with an electronic platform, both for physical and electronic meetings, has strengthened accountability of corporate representatives in Turkey, and enabled active participation of shareholders in corporate decisions ranging from executive remuneration to representation of women on company boards. The bilingual structure furthermore introduced a level field for foreign and local shareholders to be heard in key corporate decisions. ${ }^{[23]}$

The usage of a digital signature framework for every operation in the system is a further achievement in market practices. The level of security provided by the electronic signature framework has ensured that all GM-related processes such as confirmation of attendance, proxy assignment, sharing of information, etc. are performed by the beneficial owner only. MKK participants who are responsible for e-GEM operations can access the system only after receiving their electronic signature cards and being authorized by MKK. e-GEM allows a secure environment to establish confidentiality of some GMrelated operations that could create power imbalances between majority and minority shareholders in case that information was made transparent. Proxy assignments, number of votes represented by a particular proxy and rate of GM participation are examples of information that would affect meeting decisions through strategic voting by some parties. The system encrypts access to such information sent by shareholders before a meeting. Confidentiality of shareholder data ensures that shareholders' decisions are reflected to the fullest extent during meetings.

Electronic participation through e-GEM implemented equitable treatment of shareholders as envisaged in global principles and best practices. Any conflict of interest between majority and minority shareholders that might adversely affect GM related processes is circumvented by a high level of transparency on the level of beneficial owners. In particular, minority shareholders are protected against any possible manipulation of significant corporate information by other investors or the company before a GM. Easy, complete and secure access to updated beneficial owner information before a meeting was also a major achievement in reducing costs related to shareholder identification. By merely uploading electronically signed GM related documents, issuers indeed are one of the major beneficiaries of the system with the elimination of manual and costly pre-meeting procedures.

\footnotetext{
${ }^{[22]}$ Borsa Istanbul and MKK data.

${ }^{[23]}$ Four companies held simultaneous electronic GMs in both Turkish and English in two years following the launch of the system.
} 
The new model in Turkey harmonized local market practices in GM management with global standards and best practices. Improvements in GM operations such as implementation of STP in notification of shareholders through communication channels such as SMS, e-mail and SWIFT messages, removal of securities blockages for shareholder identification, efficiency in proxy operations, introduction of new GM notification deadlines (GMD-14) and record dates (GMD-1) raised market practices in Turkey to the level of standards set by international bodies of experts such as JWGGM and ISSA.

Novelties such as access to GM related information from a primary source, e- voting, e-proxy assignment and voting, real-time communication, disclosure of meeting information and documents through a single platform, etc. also raised the level of corporate governance principles in the country and achieved compliance with OECD and ICGN Principles and the EU Shareholder Rights Directive. The new model strengthened protection of shareholder rights, equitable treatment of shareholders, improved transparency and streamlined exercise of managerial rights, particularly for foreign shareholders.

The PDP 4.0 project, which was initiated by MKK following the transfer of PDP's management from Borsa Istanbul, will introduce new improvements in GM operations such as direct electronic voting by foreign beneficial owners through SWIFT, using ISO compliant message formats [ISO 15022 and 20022 $2^{[24]}$. Furthermore, PDP's full integration with e-MKK Information Portal platforms such as Corporate Governance and Investor Relations (e-GOVERNANCE) platform will establish MKK as a single gateway for data on investors and companies. The planned upgrades that will be finalized in 2016 will generate further significant efficiencies in all corporate actions related operations in Turkey.

Better communication between shareholders and issuers will have further positive effects on corporate democracy beyond the core functions of GMs such as its being a platform for shareholder voting. We believe that the added information transparency, both for domestic and foreign investors, will contribute to investor confidence, and will have an indirect positive effect on the level of capital markets activities in Turkey.

The electronic platform has functionalities used for both physical and electronic GM processes due to the hybrid nature of meetings in Turkey. A single electronic platform for GM management creates a significant advantage of cost efficiencies due to scale economies. Moreover, both non-listed and listed companies can outsource all or part of their GM-related processes to e-GEM. In this respect, besides direct cost efficiencies brought about by raising the level of corporate governance in Turkey, we believe that the electronic system will create multiple positive externalities for the economy, including reductions in costs of capital for companies. There is room for further analysis in determining these effects in future studies.

\footnotetext{
${ }^{[24]}$ At the moment only the ISO 15022 message format is used in notifications. However, ISO 20022 will be implemented with the wider use of XML in data entries by issuer companies in Turkey.
} 


\section{Conclusions}

The increasing international capital flows heightened the importance of corporate governance mechanisms in acquiring new capital. Large institutional investors such as sovereign and pension funds are increasingly taking corporate governance principles as well as financial performance into consideration in their investment decisions. Barriers against shareholder participation, coupled with complicated proxy processes, can divert international investors to countries with the best market practices in corporate governance. Good corporate governance practices can establish investor confidence in capital markets and create economic benefits through cost-time efficiencies and various externalities.

Efficient exercise of shareholder rights, such as in cross-border voting, is among the most important aspects of global principles and standards concerning corporate governance. Electronic GM platforms are widely recommended by global principles and standards as ideal systems that can improve corporate governance mechanisms in the world. These platforms have the capacity to implement fast and efficient infrastructures for the exercise of shareholder rights. Shareholders can participate in corporate decision processes more directly and with a broader base through electronic systems. Increased transparency of information with these platforms creates other advantages for the improvement of the level of corporate democracy by protecting the rights of minority shareholders.

In this context, we believe that the new Turkish model of GM process management is a unique example for other market participants, and other regulatory and post-trade institutions in the world. The model was set up with the backing of legal reforms in the form of the new Commercial Code, the new Capital Markets Law and related secondary regulations that were drafted by taking into account international efforts towards establishing global market practices for GM processes. These regulations paved the way for an electronic infrastructure for GM process management by mandating all publicly traded companies in Turkey to convene electronic as well as physical GMs and by giving the Turkish CSD, MKK, the responsibility to establish a single electronic GM platform. MKK's e-GEM has enabled issuers, beneficial owners and proxy holders to manage the whole GM process that starts with notification of shareholders and ends with sharing of post-GM information and documents.

Turkey is a good candidate to attract more foreign institutional investment in the near future thanks to the new legal framework and the electronic infrastructure that has dramatically improved participation of shareholders in corporate decision mechanisms. We believe that the improved position of foreign institutional investors in the new model, coupled with the ease of access to corporate information, will further implement better management practices in the country; these, therefore, will have direct positive effects on the Turkish economy. 


\section{References}

Alcock, R., Daly, A., Conde, C., and Robinson, A.A. (2006). Electronic Proxy Voting in Australia. Allens Arthur Robinson Publications.

Ararat, M. and Eroğlu, M. (2002). "Istanbul Stock Exchange Moves First on Mandatory Electronic Meeting," The Harvard Law School Forum on Corporate Governance and Financial Regulation, 30 November 2012. Available [online] at: http://blogs.law.harvard.edu/corpgov/2012/11/06/ istanbul-stock-exchange-moves-first-on-mandatory-electronic-voting/\#comments

CESAME, (2008). "Solving the Industry Giovannini Barriers to Post-trading within the EU," 28 November 2008. Available [online] at: http://ec.europa.eu/internal_market/financial-markets/docs/ cesame/cesame_report_en.pdf

Ergincan, Y. (2011). "Mobile Corporate Governance: A Model Proposal for Modern Corporate Governance and Investor Relations," Boğaziçi Journal: Review of Social, Economic and Administrative Studies, Vol. 25, No. 1: 171-200.

Ergincan, Y. and Gürbüz, O. (2004), Corporate Governance: Status in Turkey and Suggestions for Improvement, $1^{\text {st }}$ edition. Istanbul: Literatur Publishing

Ergincan, Y. and Yayla, Ü. (2011). "General Meeting Attendance by Electronic Means in the New Turkish Commercial Code and Shareholder Representation," Capital Markets Journal, OctoberDecember 2011, No. 8: 14-15.

EU Directive (2007/36/EC) on the Exercise of Certain Rights of Shareholders in Listed Companies. Available [online] at: http://eur-lex.europa.eu/LexUriServ/LexUriServ.do?uri=OJ:L:2007:184:0017 :0024:EN:PDF

ICGN, (2014). "Global Governance Principles EU Shareholders". Available [online] at: http://www. fsa.go.jp/en/refer/councils/corporategovernance/reference/icgn.pdf.

ISSA, (2013). "Global Principles for Corporate Actions and Proxy Voting: Progress Update Report". Available [online] at: http://www.issanet.org/pdf/2013-09_CAWG_report.pdf

ISSA, (2012). "Global Principles for Corporate Actions and Proxy Voting". Available [online] at: http://www.issanet.org/pdf/ISSA_WG_CA-PV_Final_Report_June2012.pdf

JWGGM, (2010). "Market Standards for General Meetings". Available [online] at: http://www.ebffbe.eu/uploads/Market\%20Standards\%20for\%20General\%20Meetings.pdf

Kelleher, E. (2012). “Turkey Moves First in e-voting,” Financial Times, 8 October 2012.

Keser Berber, L. and Yayla, Ü. (2012). "Application of Electronic General Assembly in Turkey,” Regesta Corporate Law Journal, Istanbul Chamber of Commerce. Vol. 2, No. 3: 13-49.

Kobler, G P. (1998). "Shareholder Voting Over the Internet: A Proposal For Increasing Shareholder Participation in Corporate Governance," Alabama Law Review, Vol. 49, No. 2: 673-700

OECD, (2004). Principles of Corporate Governance. OECD Publications.

------, (2011). The Role of Institutional Investors in Promoting Good Corporate Governance. OECD Publications.

Official Gazzette, (2004). No. 25355, Electronic Signature Law, No. 5070, 23 January 2004.

------, (2011). No. 27846, Turkish Commercial Code, No. 6102, 14 February 2011.

------, (2012). No. 28513, Capital Market Law, No. 6362, 30 December 2012.

Yayla, Ü. (2013). General Meetings of Joint Stock Companies. Istanbul: On İki Levha Publishing. 


\section{Appendix}

The table below gives descriptive statistics on ten variables consisting of the share of capital represented in the total capital of 234 companies that held physical and electronic meetings and results of a normality test on those variables:

\begin{tabular}{cccccc}
\hline Variables* & Average & Std. Dev. & Minimum & Maximum & Jarqua-Bera** \\
\hline f_2011 & 0.616 & 0.998 & 0 & 0.237 & 31.582 \\
\hline t_2011 & 0.616 & 0.998 & 0 & 0.237 & 31.582 \\
\hline f_2012 & 0.619 & 0.998 & 0 & 0.242 & 341.909 \\
\hline t_2012 & 0.619 & 0.998 & 0 & 0.242 & 341.909 \\
\hline e_2013 & 0.032 & 0.284 & 0 & 0.057 & 483.143 \\
\hline f_2013 & 0.568 & 0.993 & 0 & 0.281 & 279.822 \\
\hline t_2013 & 0.600 & 0.993 & 0 & 0.279 & 319.640 \\
\hline e_2014 & 0.043 & 0.356 & 0 & 0.068 & 308.180 \\
\hline f_2014 & 0.609 & 0.999 & 0 & 0.257 & 321.110 \\
\hline t_2014 & 0.653 & 0.999 & 0 & 0.253 & 453.977 \\
\hline
\end{tabular}

*: $f=$ Physical participation, $e=$ Electronic participation, $t=$ Total participation

**: All related $p$ values are lower than (0.01)

A first observation on Jarque-Bera statistics shows that none of the variables have normal distributions. Another observation is that the share of capital represented by physical participation did not change dramatically while the total capital represented in GMs went up significantly by 2014. 'Wilcoxon signed rank test' was used for significance tests of these results as illustrated in the table below. ${ }^{[25]}$

\begin{tabular}{ccccc}
\hline Variable 1 & Variable 2 & V & P & Result \\
\hline t_2014 & t_2013 & 13,658 & $\mathbf{0 . 0 0 1}$ & t_2014 $>$ t_2013 \\
\hline t_2014 & t_2012 & 14,768 & $\mathbf{0 . 0 0 0}$ & t_2014 $>$ t_2012 \\
\hline t_2014 & t_2011 & 15,360 & $\mathbf{0 . 0 0 0}$ & t_2014 $>$ t_2011 \\
\hline f_2014 & f_2013 & 9,608 & 0.858 & f_2014 $=$ f_2013 \\
\hline f_2014 & f_2012 & 9,607 & 0.147 & f_2014 $=$ f_2012 \\
\hline f_2014 & f_2011 & 10,698 & 0.585 & f_2014 $=$ f_2011 \\
\hline f_2013 & f_2012 & 9,423 & 0.149 & f_2013 $=$ f_2012 \\
\hline f_2013 & f_2011 & 10,279 & 0.309 & f_2013 $=$ f_2011 \\
\hline f_2012 & f_2011 & 9,261 & 0.525 & f_2012 $=$ f_2011 \\
\hline e_2014 & e_2013 & 8,779 & $\mathbf{0 . 0 0 0}$ & e_2014 $>$ e_2011 \\
\hline
\end{tabular}

[25] 'Wilcoxon signed rank test' was used because this test does not assume that the data fit the normal distribution and it has low sensitivity to outliers. Its only disadvantage when compared to 't-test' is that it reacts to differences in shapes of distributions even in situations where differences in central tendency are more important. On the other hand, since we compare the annual values of the same firm set in this study, and as a result since both skewness and kurtosis values remain almost constant for the period, we do not need to question the validity of $\mathrm{p}$ values below. Another reason improving our confidence in these results is the fact that both the unpaired version 'Wilcoxon rank sum test' and the ordinary 't-test' scores lead us to the same path. 